Article

\title{
Cellulose Beads Derived from Waste Textiles for Drug Delivery
}

\author{
Beini Zeng *, Xungai Wang and Nolene Byrne * \\ Institute for Frontier Materials, Geelong Waurn Ponds Campus, Deakin University, \\ Waurn Ponds 3216, Victoria, Australia; xungai.wang@deakin.edu.au \\ * Correspondence: b.zeng@deakin.edu.au (B.Z.); nolene.byrne@deakin.edu.au (N.B.)
}

Received: 9 June 2020; Accepted: 15 July 2020; Published: 21 July 2020

\begin{abstract}
Cellulose beads were successfully prepared from waste denim using a dissolutionregeneration approach with ionic liquids as the dissolving solvent. Cellulose beads with different morphologies were achieved by altering the dissolving and coagulating solvents. The morphological differences were quantified by $\mathrm{N}_{2}$ physisorption. The impact of morphology on the cellulose beads' potential application was investigated in the context of drug loading and release. The results show that the fibrous morphology showed a better loading capacity than the globular analogue due to its higher surface area and pore volume.
\end{abstract}

Keywords: porous cellulose; porous structure; textile recycling; waste utilisation; drug delivery

\section{Introduction}

The negative environmental impacts of the textile industry have been in the spotlight in recent years due to the increasing public awareness around sustainability and climate change. One of the pressing issues faced by the textile industry is the increasing amount of textile waste [1,2]. Global textile fibre production has reached 150 million tonnes, and 92 million tonnes of solid waste is generated annually [3]. Cotton is extensively utilised in the textile industry and accounts for $24 \%$ of the total textile fibre production [4]. It is also the dominating component of the largest fashion item on the market, denim. Hence, denim recycling remains a big concern for the textile and fashion industry. Cotton is mainly composed of cellulose, which is a sustainable, renewable, and biocompatible natural polymer with versatile applications that currently utilised in many industries, including the paper and pulp industry and the food packaging industry [5]. Cellulose has also been employed in a variety of more advanced applications such as energy storage, drug delivery, and tissue engineering [6-8]. Since cotton itself is an excellent cellulose-rich feedstock, there is potential to exploit waste textile products and convert them into value-added cellulose-based products [9].

One such advanced product is cellulose beads, also known as cellulose particles or microspheres. It is a high-performance material with a wide range of applications [10-12]. Cellulose beads have a high porosity that make them suitable as absorbents for various substrates, such as heavy metal ions and enzymes for environmental remediation and the food industry, respectively [13,14]. Cellulose beads are also a promising filling material because of their spherical shape that leads to low flow resistance in chromatographic columns [11]. Compared with organic and inorganic based beads, cellulose beads have been shown to possess higher mechanical stiffness than silica-based beads and have a comparatively simple manufacturing process compared with synthetic polymer-based beads $[10,15,16]$. Additionally, cellulose beads are particularly promising for biomedical applications, including as carriers for drug molecules for oral delivery because of the biocompatibility of cellulose while achieving a high surface area, porosity, and low density of an aerogel [17]. In the literature, cellulose beads are usually categorised as a type of aerogel material with a spherical geometry because 
they have similar preparation procedures $[16,18]$. The preparation process for cellulose beads can be divided into three main steps: dissolution of cellulose, spheronisation, and coagulation [12]. Drying under special conditions is an optional step to preserve the porosity of beads in the dry state [19]. The size of cellulose beads can range from micrometres to a few millimetres, which is largely determined by the shaping method [20-22]. The spherical droplets are added into a bath that contains an anti-solvent for regeneration. The porous structure of cellulose beads is formed in this step through a continuous exchange between the dissolving solvent and anti-solvent [23]. The inner porous structure or morphology of cellulose beads is an important factor in determining its performance in various applications such as the loading capacity of drug molecules [24,25]. The most common morphologies that have been reported for cellulose aerogels are fibrous and globular structures. The fibrous morphology is composed of three-dimensional fibre-like entanglements that are inherited from the cellulose polymer chain, while the globular morphology is composed of globule-like aggregations [26,27]. The morphology can be tuned by altering the polymer concentration, the choice of dissolving solvent/anti-solvent, and the type of functionalisation applied to cellulose molecules $[20,28,29]$.

In our previous study on cellulose aerogels [9], it was shown that the anion of the ionic liquid, which was used to dissolve the cellulose feedstock, had a prominent influence on the porous structure of cellulose aerogel. The major aim of the present study was to prepare cellulose beads from waste denim with different morphologies and porosity and to investigate the influence of the different morphologies on drug delivery efficiency.

\section{Materials and Methods}

\subsection{Materials}

Waste denim fabrics are made of $100 \%$ cotton. Sodium hydroxide $(\mathrm{NaOH})$ (anhydrous pellets) was purchased from Sigma-Aldrich (Sydney, Australia). Two ionic liquids (ILs), 1-butyl-3methylimidazolium chloride $(\mathrm{BmimCl})$ and 1-butyl-3-methylimidazolium acetate $(\mathrm{BmimAc})$ were purchased from IOLITEC, Heilbronn, Germany. Both ILs were used as received.

The two selected drugs, theophylline (Thp) and lidocaine hydrochloride monohydrate ( $\mathrm{LiHCl})$, were purchased from Sigma Aldrich. Distilled water was used as the solvent to prepare drug solutions.

\subsection{Experimental Methodology}

\subsubsection{Preparation of Cellulose Beads from Denim}

As illustrated in Figure 1, denim fabrics were shredded and milled into 0.2-mm powders and pre-treated in aqueous $\mathrm{NaOH}$ solution $(10 \% \mathrm{w} / \mathrm{w})$ at $90^{\circ} \mathrm{C}$ for $15 \mathrm{~h}$. This pre-treatment reduced the molecular weight of denim and removed dirt. The obtained slurry was then rinsed with distilled water until $\mathrm{NaOH}$ was fully removed. The rinsed slurry was dried under $80^{\circ} \mathrm{C}$ for $12 \mathrm{~h}$ [30].

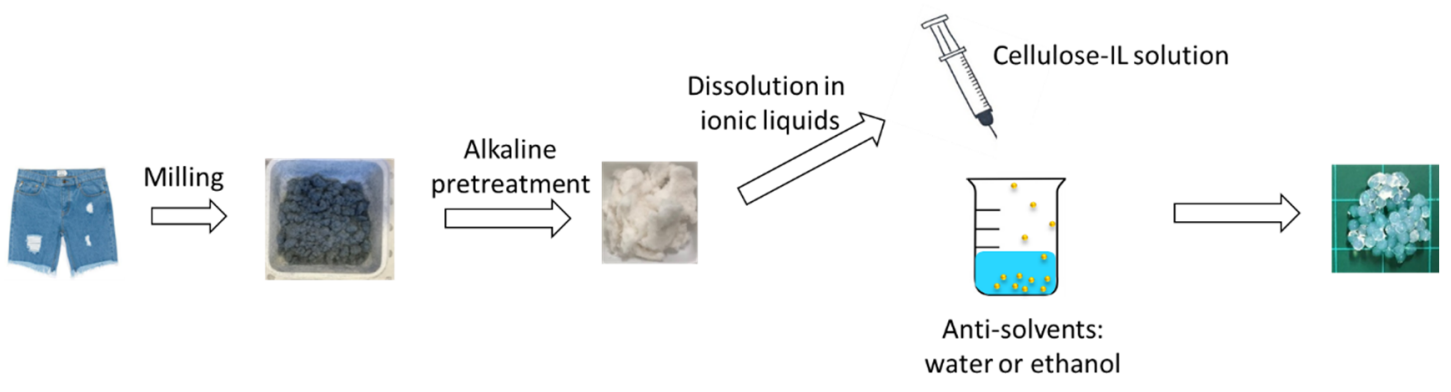

Figure 1. A schematic for the preparation of cellulose beads from waste denim. 
The dissolution of denim in both ILs was conducted at $100{ }^{\circ} \mathrm{C}$ with magnetic stirring. The completeness of dissolution was verified by means of polarised microscopy when no crystalline structure could be observed. The denim concentration was fixed at $4 \mathrm{wt} . \%$ in this study.

The denim-IL solution was transferred into a 3-mL syringe and was extruded at a constant rate (manually). While the solution was being extruded from syringe nozzle, two methods were adopted for producing beads. For the cellulose-BmimAc solution, a blade was used to shear off the solution to form a bead. For cellulose-BmimCl, the solution was too viscous to be sheared off; therefore, scissors were used to cut the solution into spheres. The spherical shaped droplets were then dropped directly into a coagulation bath. Distilled water and ethanol were chosen as coagulation baths. The bath was changed every $1 \mathrm{~h}$ in the first $4 \mathrm{~h}$ and then immersed in water for $24 \mathrm{~h}$. When ethanol was used as the coagulation bath, the obtained beads were washed with distilled water to exchange ethanol with water before drug loading. Table 1 lists the various cellulose beads prepared from waste denim and the solvent and coagulating solvent used.

Table 1. The ionic liquids (ILs) and coagulants used for the preparation of three types of cellulose beads.

\begin{tabular}{ccc}
\hline Bead Name & Dissolving Solvent & Coagulant \\
\hline $\mathrm{Bmim}_{\mathrm{Cl}} \mathbf{l}_{\text {water }}$ & $\mathrm{BmimCl}$ & Water \\
$\mathrm{Bmim}_{\mathrm{Ac}}$ water & $\mathrm{BmimAc}$ & Water \\
$\mathrm{Bmim} A \mathrm{c}_{\text {ethanol }}$ & $\mathrm{BmimAc}$ & Ethanol \\
\hline
\end{tabular}

\subsubsection{Characterisations of Cellulose-IL Solutions and Cellulose Beads}

The rheological measurements of the cellulose-IL solutions were conducted on an ARES-G2 Rheometer (TA Instruments, New Castle, DE, USA) equipped with a Peltier temperature control system and a $40 \mathrm{~mm}$ parallel geometry. The gap was set at $50 \mathrm{~mm}$ for all samples. Oscillation frequency sweep measurements of the solution were conducted at $25^{\circ} \mathrm{C}$ in the frequency range of 0.01 to $100 \mathrm{rad} / \mathrm{s}$ and the strain was set at $0.1 \%$. Complex viscosity, storage modulus, and loss modulus were recorded.

The diameters of the fully coagulated beads were measured using a Vernier calliper and were controlled within $2.0 \pm 0.1 \mu \mathrm{m}$. Thirty beads were measured for each type of beads. Supercritical $\mathrm{CO}_{2}$ drying was used to remove anti-solvents without influencing the solid content of cellulose beads so that the characterisations of the inner pore structure could be determined. All of the wet beads were washed with excessive ethanol to replace water and were then immersed in ethanol for $12 \mathrm{~h}$ before drying. The drying was performed on a Leica critical point drier (EM CPD300, Leica Microsystems, Wetzlar, Germany). The porosity of the supercritical-dried beads was analysed by $\mathrm{N}_{2}$ physisorption measurement on Quantachrome Autosorb iQ3 (Quantachrome Instruments, Boynton Beach, FL, USA). Samples were degassed at $80{ }^{\circ} \mathrm{C}$ for $10 \mathrm{~h}$ before being subjected to the 80-point physisorption measurements. The surface area was obtained by Brunauer-Emmett-Teller (BET) theory analysis on relative pressure $0.05-0.25$, and the pore size distribution was analysed from the desorption curve based on the Barrett-Joyner-Halenda (BJH) theory with the exclusion of points with relative pressure below $0.3[31,32]$. Scanning electron microscopy (SEM) imaging was performed on Zeiss Supra 55V (Zeiss, Oberkochen, Germany) to observe the morphologies of cellulose beads. All the samples were coated with a 5-nm layer of gold before imaging.

\subsubsection{Drug Loading and In-Vitro Release}

Lidocaine hydrochloride monohydrate $(\mathrm{LiHCl})$ and theophylline (Thp) were selected as the representative substances, which are commonly employed for evaluating the drug delivery efficiency of different porous materials $[25,33,34]$. $\mathrm{LiHCl}$ is a type of amide-class local anaesthetics that is used to relieve nerve pain. Thp is a xanthine derivative, which is commonly used for asthma treatment. Thp molecules are immediately absorbed after oral administration, which relaxes the pulmonary blood vessels and the smooth muscles of bronchial airways and reduces the responsiveness of the airway to 
allergy-stimulating chemicals. Their solubilities in water, the concentrations used in the present study, and their indicative wavelengths in the UV-Vis spectrometer are listed in Table 2.

Table 2. Two drugs selected for the drug delivery test.

\begin{tabular}{ccccc}
\hline Drug Name & Synonym & $\begin{array}{c}\text { Solubility in Water } \\
(\mathbf{m g} / \mathbf{m L})\end{array}$ & $\begin{array}{c}\text { Solution Concentration } \\
\text { for Drug Loading } \\
(\mathbf{m g} / \mathbf{m L})\end{array}$ & $\begin{array}{c}\text { Wavelength } \\
\text { in UV-Vis } \\
(\mathbf{n m})\end{array}$ \\
\hline $\begin{array}{c}\text { Lidocaine hydrochloride } \\
\text { monohydrate (LiHCl) } \\
\text { Theophylline (Thp) }\end{array}$ & $\begin{array}{c}\text { 2-(Diethylamino)-N-(2,6- } \\
\text { dimethylphenyl)acetamide } \\
\text { hydrochloride hydrate } \\
\text { Dimethylxanthine }\end{array}$ & 147 & 20 & 218 \\
\hline
\end{tabular}

For each drug, a concentration measurement was carried out to correlate the absorption value with the solution concentration using the Cary 300 UV-Vis spectrometer (Agilent Technologies, Santa Clara, CA, USA). Four concentrations of drug solutions were prepared with $0.1 \mathrm{~N} \mathrm{HCl}$ and the absorption values were recorded. The standard concentration curves of $\mathrm{LiHCl}$ and Thp are shown in Figures S1 and S2.

\section{Drug Loading}

The as-prepared wet beads were immersed in drug solutions for $24 \mathrm{~h}$. The loaded beads were then removed from the drug solutions and dried in air overnight. The amount of incorporated drugs was obtained on the basis of the weights of dried beads before and after loading the drugs. Each batch involved 15 beads, and all the experiments were repeated three times. The loading capacity is calculated as follows:

$$
\text { Loading capacity }(\%)=\frac{\text { weight of loaded beads }- \text { weight of unloaded beads }}{\text { weight of unloaded beads }} \times 100 \text {. }
$$

\section{In Vitro Drug Release}

The dried loaded beads (15-25 beads in each batch) were immersed in 250-mL $0.1 \mathrm{~N} \mathrm{HCl}$ buffer solution and constantly stirred at a fixed stirring rate of $100 \mathrm{rpm}$ at $37.0 \pm 0.5^{\circ} \mathrm{C}$. The release protocol is designed according to the USP paddle method with minor adjustments. The stirring paddle was maintained at the same position for each test. Four millilitres of the solution was taken for UV-Vis measurement at fixed five-minute time intervals for the first $20 \mathrm{~min}$ and then every $10 \mathrm{~min}$ from 20 to $80 \mathrm{~min}$. The samples were taken at the same position each time to avoid deviations. All the experiments were performed in triplicate. The amount of the drug released was calculated using the obtained concentration-absorption curve. In the end, the drug release of each sample was plotted according to the percentage of the initial amounts versus time. The release efficiency is calculated as follows:

$$
\text { Release efficiency }(\%)=\frac{\text { release drug amount }}{\text { loaded drug amount }} \times 100
$$

The swelling capacity of the beads was measured using a gravimetric method [35]. The dry beads were weighed and immersed in $0.1 \mathrm{~N} \mathrm{HCl}$ solution for $2 \mathrm{~h}$ at $37.0 \pm 0.5^{\circ} \mathrm{C}$. The swelled beads were gently wiped with Kimwipes and weighed.

\section{Results and Discussion}

Figure 2 shows the surfaces and cross sections of all three types of beads prepared from waste denim. It is observed that all the beads have a non-porous surface morphology. This is a commonly formed structure resulting from the rapid outflow of the solvent when the polymer solution is exposed to the anti-solvent [36]. The cross-sections of each bead showed the inner morphology differences; two distinctly different porous structures were obtained by varying the dissolving solvent. 
$\mathrm{BmimCl}_{\mathrm{water}}$ has a cross-section that comprises a dense fibrous network at the nanoscale (Figure 2c). This fibrous structure is believed to be inherent from the intra- and inter-molecular hydrogen bonds of cellulose chains [16]. The cross-section of BmimAc $\mathbf{c}_{\text {water }}$ (Figure 2e) appears to be composed of micro-sized globules, which are approximately $0.3 \sim 0.5 \mu \mathrm{m}$; these globular aggregates are fibrous at higher magnification (Figure 2f). This globular morphology has been reported in aerogels produced using various solvent systems and is regarded as the result of cellulose aggregations when hydrogen bonds are being rebuilt as the dissolving solvent leaves during coagulation [37]. These distinct morphological differences observed in the cellulose beads resulting from the use of different ILs as the dissolving solvents could be attributed to the difference in the solution state. Rheological measurements performed on both denim-IL solution samples at room temperature where coagulation occurs (Figure S3), show that the denim-BmimCl solution remains a liquid at room temperature but has much higher moduli than the denim-BmimAc solution. This indicates much lower mobility of cellulose molecules when dissolved in $\mathrm{BmimCl}$ compared with BmimAc, which may account for the fibrous morphology that forms under conditions when molecular aggregation is prevented due to slower coagulation kinetics. A simplified scheme is shown in Figure S4 for two systems. This explanation could also apply to previous observations of cellulose aerogels produced using aqueous solvent systems. In the literature, globular morphology has been observed when cellulose solutions are in the liquid state, while fibrous morphology appears when cellulose solutions are solidified or gelled when $\mathrm{N}$-Methylmorpholine- $\mathrm{N}$-oxide monohydrate and aqueous $\mathrm{NaOH}$ solution are used as the dissolving solvent $[27,29]$.
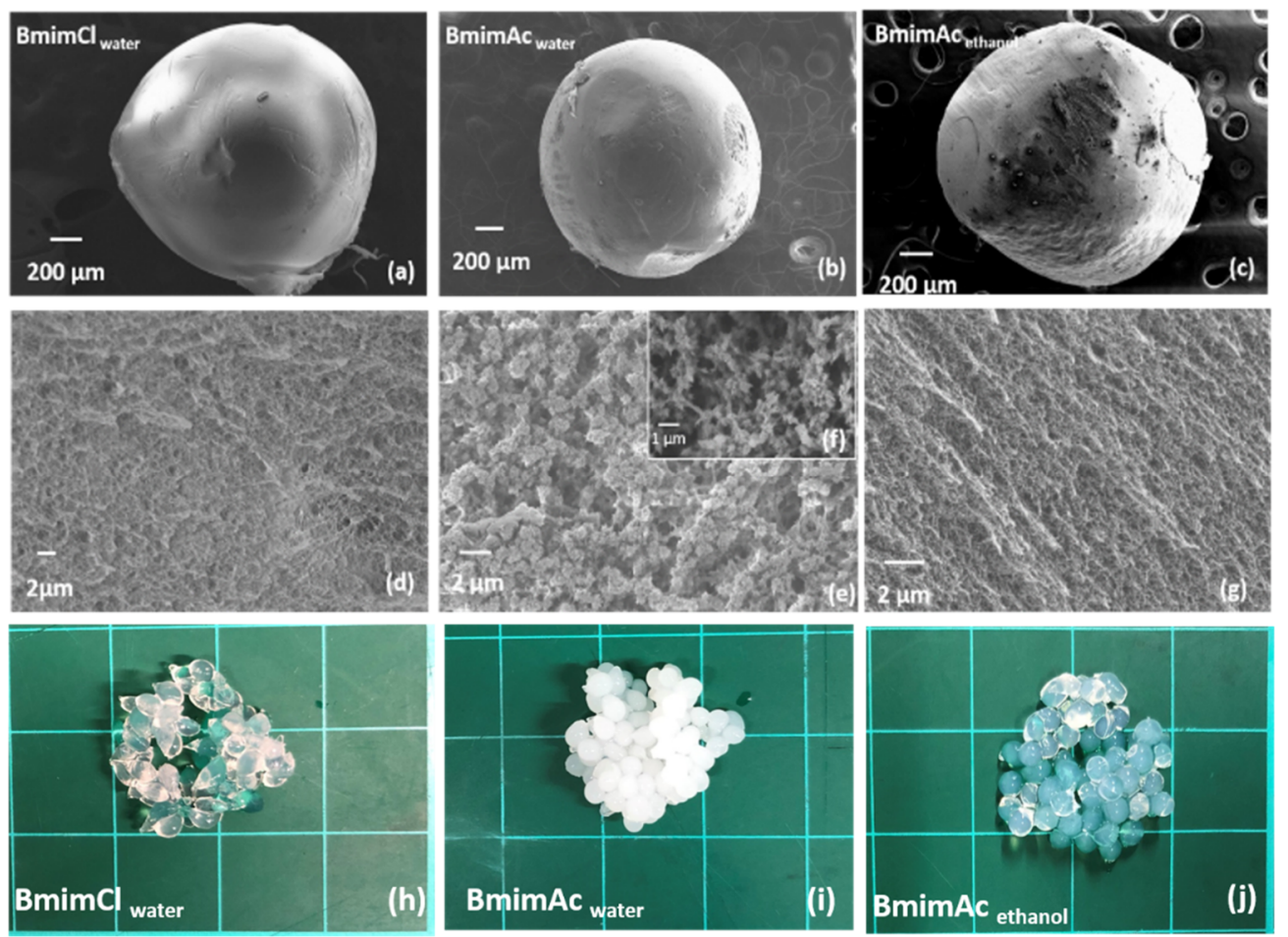

Figure 2. Scanning electron microscopy (SEM) images of surfaces (a-c) and cross sections (d-g) of cellulose beads prepared from denim; (a) and (d) $\mathrm{BmimCl}_{\text {water }}$ (b), (e) and (f) $\mathrm{BmimAc}_{\mathrm{water}}$ ( (c) and (g) BmimAc $\mathbf{A c t h a n o l}_{\text {e }}(\mathbf{h}-\mathbf{j})$ present the appearances of cellulose beads.

The morphology can also be manipulated by using the anti-solvent (coagulating solvent); when ethanol was used as the coagulating solvent for the cellulose-BmimAc sample (BmimAcethanol), a change from globular to fibrous network was observed, similar to that of $\mathrm{BmimCl}_{\text {water }}$ (Figure $2 \mathrm{~g}$ ). This morphological transition could indicate a slower diffusion rate of the IL molecules in ethanol compared with that in water because water was found to be a more effective anti-solvent than ethanol 
at breaking cellulose-IL bonds [38]. The reduced escaping speed of BmimAc may give rise to the steady rebuild of the hydrogen bonds among cellulose molecules, thus maintaining the intrinsic fibrous structure. The morphological differences also impact the beads' appearance in terms of transparency, as shown in Figure 2. The two fibrous beads, $\mathbf{B m i m C l}_{\text {water }}$ and $\mathrm{BmimAc}_{\text {ethanol, }}$, are highly transparent, while BmimAc water is opaque.

Table 3 presents the porosity and physical characterisations of each bead after supercritical drying, as measured by $\mathrm{N}_{2}$ physisorption. BmimA $\mathbf{c}_{\text {water }}$ has the lowest surface area among the three samples, and $\mathrm{BmimCl}_{\text {water }}$ shows a slightly higher surface area than $B$ mim $A \mathbf{c}_{\text {ethanol }}$. The average pore size of the fibrous morphology (for both BmimAcethanol and $\mathrm{BmimCl}_{\text {water }}$ ) is the same ( $34.3 \mathrm{~nm}$ ), which is significantly larger than the globular morphology $(13.9 \mathrm{~nm})$. This is likely due to the considerably higher diffusion rates of the solvent and anti-solvent in the case of BmimAc $\mathbf{c}_{\text {water }}$. The cumulative pore volumes of the fibrous beads are consequently larger than that of globular beads with the larger average pore size. Between the two fibrous beads, $B$ mimAc $c_{\text {ethanol }}$ has a higher cumulative pore

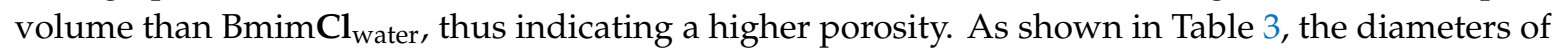
all the beads are similar; however, differences in the weight of the beads in the dry state are noted. Beads prepared from BmimAc $\mathbf{c}_{\text {water }}$ have a weight of $0.44 \pm 0.04 \mathrm{mg}$, which is higher than that of $\mathrm{BmimAc}_{\text {ethanol }}(0.26 \pm 0.01 \mathrm{mg})$ and $\mathrm{BmimCl}_{\text {water }}(0.35 \pm 0.05 \mathrm{mg})$. This indicates a higher solid content in BmimA $\mathbf{c}_{\text {water }}$ than the other two beads and thus a lower porosity. This result is consistent with the different surface areas of the beads. Overall, the porosities of beads prepared from waste denim here are comparable with the reported cellulose beads and aerogels in various shapes, the pore sizes of which are mostly mesopores $(2-50 \mathrm{~nm})$, resulting in an surface area of $200-500 \mathrm{~cm}^{3} / \mathrm{g}[27,39]$.

Table 3. Porosity characterisations of cellulose beads.

\begin{tabular}{|c|c|c|c|c|c|c|}
\hline Bead Name & $\begin{array}{c}\text { Specific } \\
\text { Surface Area } \\
\left(\mathrm{m}^{2} / \mathrm{g}\right)\end{array}$ & $\begin{array}{l}\text { Average Pore } \\
\text { Size (nm) }\end{array}$ & $\begin{array}{l}\text { Pore Volume } \\
\quad\left(\mathrm{cm}^{3} / \mathrm{g}\right)\end{array}$ & $\begin{array}{l}\text { Diameter of the } \\
\text { Wet Beads } \\
(\mathrm{mm})\end{array}$ & $\begin{array}{c}\text { Diameter of } \\
\text { Dry Beads (mg) }\end{array}$ & $\begin{array}{c}\text { Weight of } \\
\text { Dry Beads } \\
\text { (mg) }\end{array}$ \\
\hline $\mathrm{BmimCl}_{\text {water }}$ & 382 & 34.3 & 2.4 & $2.00 \pm 0.08$ & $0.75 \pm 0.04$ & $0.35 \pm 0.05$ \\
\hline BmimA $\mathbf{c}_{\text {ethanol }}$ & 348 & 34.3 & 3.7 & $2.00 \pm 0.09$ & $0.65 \pm 0.04$ & $0.26 \pm 0.01$ \\
\hline
\end{tabular}

The loading of the drug was achieved by immersing beads in the drug solution for $24 \mathrm{~h}$. The amount of incorporated drug in the bead was determined by the weight difference of the dry bead before and after the drug loading. $\mathrm{LiHCl}$ and Thp were chosen as model drugs [25]. Because of their different solubilities in water, the concentration of each drug was different: $20 \mathrm{mg} / \mathrm{mL}$ for $\mathrm{LiHCl}$ and $4 \mathrm{mg} / \mathrm{mL}$ for Thp was used for the loading test. The loading capacity (\%) was determined by the weight ratio of the amount of absorbed drug substrate to the weight of the unloaded dry bead, as shown in Figure 3.

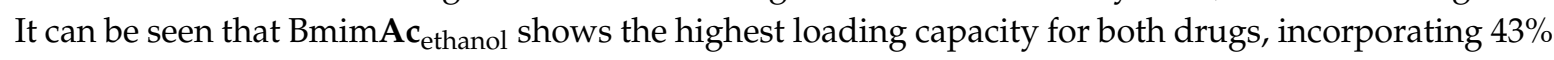
and $10 \%$ for $\mathrm{LiHCl}$ and $\mathrm{Thp}$, respectively (the loading capacity values for all beads loading are listed in Table S1). The significantly lower loading ratio of Thp when compared to $\mathrm{LiHCl}$ is due to the lower drug content used for Thp loading. BmimCl $\mathbf{C l}_{\text {water }}$ has a slightly lower loading capacity than that of $B$ mimAcethanol, which could be attributed to the lower surface area and smaller pore volume measured for $\mathrm{BmimCl}_{\text {water. }}$ Bmim $\mathbf{A c}_{\text {water, }}$, with a globular morphology, shows much lower loading capacities than beads with fibrous morphology. Since BmimAc $\mathbf{c}_{\text {water }}$ has the lowest pore volume, fewer loading sites for the drug molecules are present. This positive correlation between porosity (both surface area and pore volume) and loading capacity has been previously found in investigations of various drug delivery systems $[25,40]$. 


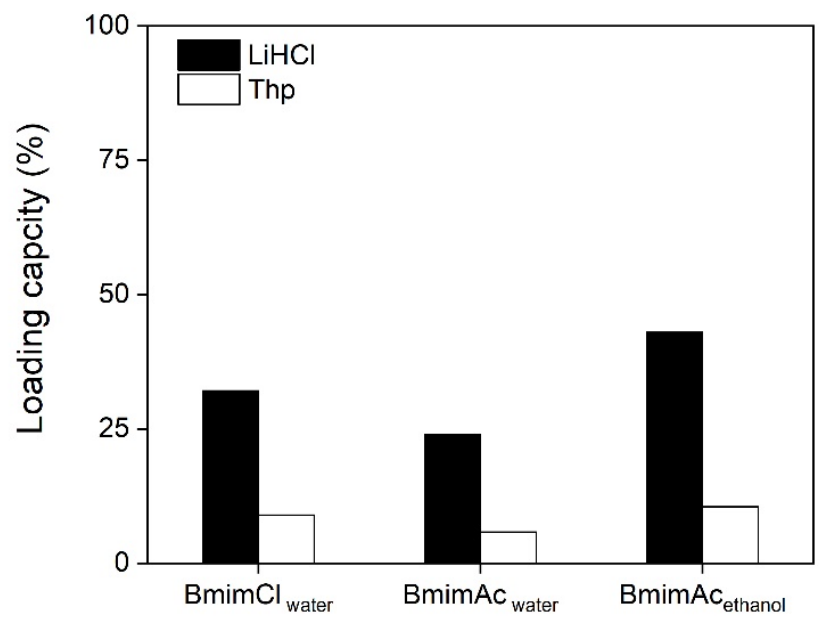

Figure 3. Loading capacities of cellulose beads prepared from waste denim.

The loaded beads were then placed in $0.1 \mathrm{~N} \mathrm{HCl}$ at $37.0 \pm 0.5^{\circ} \mathrm{C}$, which mimics the stomach environment, to test their in vitro release profile over an 80 -min period, as suggested by Yildir et al. [25]. The release curves are shown in Figure 4. It can be seen that regardless of morphology, the majority of the loaded drug was released in the initial five minutes followed by a steady release thereafter. This burst release is commonly observed and is due to the fact that most of the drug is absorbed on the surface of the bead [12]. BmimAc $\mathbf{c}_{\text {water }}$ shows the lowest initial release for both drugs, which is likely due to a smaller average pore diameter. The smaller pore diameter could lead to more capillary condensation that enables more compact storage in the pores. When the beads are immersed in the suitable media, the absorbed drug molecules diffuse out in an ordered manner. The molecules that are stored inside the nanopores have to queue up, thus resulting in a sustained release behaviour. The release curves for $\mathrm{BmimAc}_{\text {ethanol }}$ and $\mathrm{BmimCl}_{\text {water }}$ are similar, as they both have a fibrous morphology. The swelling capacity of the beads is an important characteristic that influences the diffusion of the absorbed substrate. Table 4 lists the swelling capacities of three beads. It can be seen that in the beads with globular morphology, Bmim $\mathbf{A} \mathbf{c}_{\text {water }}$, has the lowest swelling capacity. This is consistent with the lower release profile, while both fibrous bead types have similar swelling capacities.
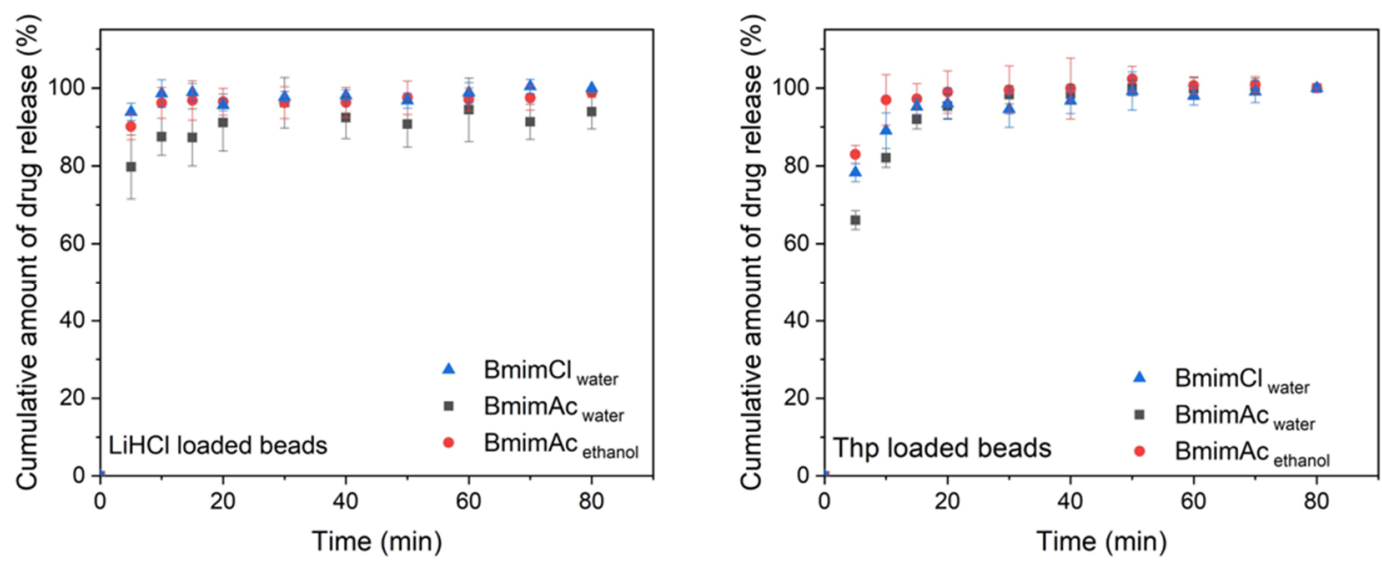

Figure 4. In vitro drug release curves for cellulose beads prepared from waste denim.

Table 4. Swelling capacities of cellulose beads prepared from waste denim.

\begin{tabular}{cccc}
\hline & BmimCl $_{\text {water }}$ & BmimAc $_{\text {water }}$ & Bmim Ac $_{\text {ethanol }}$ \\
\hline Swelling capacity & $59.3 \%$ & $48.3 \%$ & $76.4 \%$ \\
\hline
\end{tabular}




\section{Conclusions}

Three types of cellulose beads were prepared from waste denim with distinct morphologies and porosities by varying the IL used for dissolution and the coagulating solvent. By characterising the porous structure and examining the drug delivery profiles of three types of beads, it can be concluded that the loading capacities of the cellulose beads were positively correlated with the nanoporous characteristics of the beads (mainly the surface area and cumulative pore volume). Cellulose beads produced from $\mathrm{BmimCl}$ in water performed the best among the varieties, with $43 \%$ of their weight loaded with $\mathrm{LiHCl}$. The subsequent drug release studies showed that $70 \%-90 \%$ of the loaded drug was released in the first five minutes across an 80-min measurement period. Surface functionalisation can be applied to cellulose to further improve the loading and release profiles of cellulose beads or achieve certain controlled release according to the desired performance for specific drugs and targeted releasing locations in the human body.

Supplementary Materials: The following are available online at http://www.mdpi.com/2073-4360/12/7/1621/s1; Figure S1: The standard concentration curve of $\mathrm{LiHCl}$; Figure S2: standard concentration curve of Thp; Figure S3: rheological curves of denim-BmimCl and denim-BmimAc solutions at room temperature; Figure S4: Schematic explanation of cellulose mobility with two ILs; Figure S5: Pore size distributions of beads analysed from $\mathrm{N}_{2}$ physisorption. Table S1: loading capacities of $\mathrm{LiHCl}$ and Thp in the three types of beads.

Author Contributions: Conceptualisation, methodology, investigation, data analysis, writing, B.Z.; review and editing, funding acquisition, supervision, X.W.; conceptualisation, analysis, writing-review and editing, funding acquisition, supervision, N.B. All authors have read and agreed to the published version of the manuscript.

Funding: This research was supported by the Australian Research Council (ARC) Research Hub for Future Fibres (IH140100018) and funded by the Australian Government.

Conflicts of Interest: The authors declare no conflict of interest.

\section{References}

1. Koszewska, M. Circular Economy-Challenges for the Textile and Clothing Industry. Autex Res. J. 2018, 18, 337-347. [CrossRef]

2. Sull, D.N.; Turconi, S. Fast fashion lessons. Bus. Strat. Rev. 2008, 19, 4-11. [CrossRef]

3. Kerr, J.; Landry, J. Pulse the Fashion Industry. The Sustainbility Portal 2017. Available online: http: //www.sustainabilityportal.net/blog/pulseofthefashionindustry (accessed on 3 September 2019).

4. Sandin, G.; Peters, G.M. Environmental impact of textile reuse and recycling-A review. J. Clean. Prod. 2018, 184, 353-365. [CrossRef]

5. Klemm, D.; Heublein, B.; Fink, H.-P.; Bohn, A. Cellulose: Fascinating Biopolymer and Sustainable Raw Material. Chemin- 2005, 36, 3358-3393. [CrossRef]

6. Wang, S.; Lu, A.; Zhang, L. Recent advances in regenerated cellulose materials. Prog. Polym. Sci. 2016, 53, 169-206. [CrossRef]

7. Abeer, M.M.; Amin, M.C.I.M.; Martin, C. A review of bacterial cellulose-based drug delivery systems: Their biochemistry, current approaches and future prospects. J. Pharm. Pharmacol. 2014, 66, 1047-1061. [CrossRef]

8. Qiu, X.; Hu, S. "Smart" Materials Based on Cellulose: A Review of the Preparations, Properties, and Applications. Materials 2013, 6, 738-781. [CrossRef] [PubMed]

9. Zeng, B.; Wang, X.; Byrne, N. Development of cellulose based aerogel utilizing waste denim-A Morphology study. Carbohydr. Polym. 2019, 205, 1-7. [CrossRef] [PubMed]

10. Ganesan, K.; Budtova, T.; Ratke, L.; Gurikov, P.; Baudron, V.; Preibisch, I.; Niemeyer, P.; Smirnova, I.; Milow, B. Review on the Production of Polysaccharide Aerogel Particles. Materials 2018, 11, 2144. [CrossRef]

11. Luo, X.; Zhang, L. Creation of regenerated cellulose microspheres with diameter ranging from micron to millimeter for chromatography applications. J. Chromatogr. A 2010, 1217, 5922-5929. [CrossRef] [PubMed]

12. Gericke, M.; Trygg, J.; Fardim, P. Functional cellulose beads: Preparation, characterization, and applications. Chem. Rev. 2013, 113, 4812-4836. [CrossRef] [PubMed] 
13. Peng, S.; Meng, H.; Ouyang, Y.; Chang, J. Nanoporous Magnetic Cellulose-Chitosan Composite Microspheres: Preparation, Characterization, and Application for $\mathrm{Cu}(\mathrm{II})$ Adsorption. Ind. Eng. Chem. Res. 2014, 53, 2106-2113. [CrossRef]

14. Roy, I.; Gupta, M.N. Lactose hydrolysis by Lactozym ${ }^{\mathrm{TM}}$ immobilized on cellulose beads in batch and fluidized bed modes. Process Biochem. 2003, 39, 325-332. [CrossRef]

15. Lu, H.; Luo, H.; Leventis, N. Aerogel Handbook; Springer: New York, NY, USA, 2011.

16. Budtova, T. Cellulose II aerogels: A review. Cellulose 2019, 26, 81-121. [CrossRef]

17. García-González, C.A.; Budtova, T.; Durães, L.; Erkey, C.; Del Gaudio, P.; Gurikov, P.; Koebel, M.; Liebner, F.; Neagu, M.; Smirnova, I. An Opinion Paper on Aerogels for Biomedical and Environmental Applications. Molecules 2019, 24, 1815. [CrossRef]

18. De Cicco, F.; Russo, P.; Reverchon, E.; García-González, C.A.; Aquino, R.P.; Del Gaudio, P. Prilling and supercritical drying: A successful duo to produce core-shell polysaccharide aerogel beads for wound healing. Carbohydr. Polym. 2016, 147, 482-489. [CrossRef] [PubMed]

19. Sescousse, R.; Gavillon, R.; Budtova, T. Wet and dry highly porous cellulose beads from cellulose-NaOH-water solutions: Influence of the preparation conditions on beads shape and encapsulation of inorganic particles. J. Mater. Sci. 2010, 46, 759-765. [CrossRef]

20. Trygg, J.; Fardim, P.; Gericke, M.; Mäkilä, E.M.; Salonen, J.J. Physicochemical design of the morphology and ultrastructure of cellulose beads. Carbohydr. Polym. 2013, 93, 291-299. [CrossRef]

21. Druel, L.; Niemeyer, P.; Milow, B.; Budtova, T. Rheology of cellulose-[DBNH][CO2Et] solutions and shaping into aerogel beads. Green Chem. 2018, 20, 3993-4002. [CrossRef]

22. Ishimura, D.; Morimoto, Y.; Saito, H. Influences of chemical modifications on the mechanical strength of cellulose beads. Cellulose 1998, 5, 135-151. [CrossRef]

23. Biganska, O.; Navard, P. Morphology of cellulose objects regenerated from cellulose-N-methylmorpholine N-oxide-water solutions. Cellulose 2008, 16, 179-188. [CrossRef]

24. Trygg, J.; Yildir, E.; Kolakovic, R.; Sandler, N.; Fardim, P. Anionic cellulose beads for drug encapsulation and release. Cellulose 2014, 21, 1945-1955. [CrossRef]

25. Yildir, E.; Kolakovic, R.; Genina, N.; Trygg, J.; Gericke, M.; Hanski, L.; Ehlers, H.; Rantanen, J.; Tenho, M.; Vuorela, P.; et al. Tailored beads made of dissolved cellulose-Investigation of their drug release properties. Int. J. Pharm. 2013, 456, 417-423. [CrossRef]

26. Pircher, N.; Carbajal, L.; Schimper, C.; Bacher, M.; Rennhofer, H.; Nedelec, J.-M.; Lichtenegger, H.; Rosenau, T.; Liebner, F. Impact of selected solvent systems on the pore and solid structure of cellulose aerogels. Cellulose 2016, 23, 1949-1966. [CrossRef] [PubMed]

27. Sescousse, R.; Gavillon, R.; Budtova, T. Aerocellulose from cellulose-ionic liquid solutions: Preparation, properties and comparison with cellulose- $\mathrm{NaOH}$ and cellulose-NMMO routes. Carbohydr. Polym. 2011, 83, 1766-1774. [CrossRef]

28. Wang, Z.; Liu, S.; Matsumoto, Y.; Kuga, S. Cellulose gel and aerogel from LiCl/DMSO solution. Cellulose 2012, 19, 393-399. [CrossRef]

29. Innerlohinger, J.; Weber, H.K.; Kraft, G. Aerocellulose: Aerogels and Aerogel-like Materials made from Cellulose. In Macromolecular Symposia; Wiley Online Library: Weinheim, Germany, 2006; Volume 244, pp. 126-135.

30. Ma, Y.; Zeng, B.; Wang, X.; Byrne, N. Circular textiles: Closed loop fibre to fibre wet spun process for recycling cotton from denim. ACS Sustain. Chem. Eng. 2019, 14, 11937-11943. [CrossRef]

31. Sing, K. The use of nitrogen adsorption for the characterisation of porous materials. Colloids Surf. A Physicochem. Eng. Asp. 2001, 187, 3-9. [CrossRef]

32. Thommes, M.; Kaneko, K.; Neimark, A.V.; Olivier, J.P.; Rodriguez-Reinoso, F.; Rouquerol, J.; Sing, K.S. Physisorption of gases, with special reference to the evaluation of surface area and pore size distribution (IUPAC Technical Report). Pure Appl. Chem. 2015, 87, 1051-1069. [CrossRef]

33. Miyazaki, S.; Kubo, W.; Attwood, D. Oral sustained delivery of theophylline using in-situ gelation of sodium alginate. J. Control. Release 2000, 67, 275-280. [CrossRef]

34. Klose, D.; Siepmann, J.; Elkharraz, K.; Krenzlin, S.; Siepmann, J. How porosity and size affect the drug release mechanisms from PLGA-based microparticles. Int. J. Pharm. 2006, 314, 198-206. [CrossRef] [PubMed]

35. Ciobanu, B.C.; Cadinoiu, A.N.; Popa, M.; Desbrieres, J.; Peptu, C.A. Chitosan/poly (vinyl alcohol) hydrogels for entrapment of drug loaded liposomes. Cellul. Chem. Technol. 2014, 48, 485-494. 
36. Van De Witte, P.; Dijkstra, P.; Berg, J.V.D.; Feijen, J. Phase separation processes in polymer solutions in relation to membrane formation. J. Membr. Sci. 1996, 117, 1-31. [CrossRef]

37. Gavillon, R.; Budtova, T. Aerocellulose: New Highly Porous Cellulose Prepared from Cellulose- $\mathrm{NaOH}$ Aqueous Solutions. Biomacromolecules 2008, 9, 269-277. [CrossRef] [PubMed]

38. Gupta, K.M.; Hu, Z.; Jiang, J. Cellulose regeneration from a cellulose/ionic liquid mixture: The role of anti-solvents. RSC Adv. 2013, 3, 12794-12801. [CrossRef]

39. Cai, J.; Kimura, S.; Wada, M.; Kuga, S.; Zhang, L. Cellulose Aerogels from Aqueous Alkali Hydroxide-Urea Solution. ChemSusChem 2008, 1, 149-154. [CrossRef]

40. García-González, C.A.; Alnaief, M.; Smirnova, I. Polysaccharide-based aerogels—Promising biodegradable carriers for drug delivery systems. Carbohydr. Polym. 2011, 86, 1425-1438. [CrossRef]

C 2020 by the authors. Licensee MDPI, Basel, Switzerland. This article is an open access article distributed under the terms and conditions of the Creative Commons Attribution (CC BY) license (http://creativecommons.org/licenses/by/4.0/). 